\title{
PSYCHE
}

VOL. XVII.

AUGUST, 1910.

No. 4.

\section{OBSERVATIONS ON THE EARLY STAGES OF TWO APHIDIINE PARASITES OF APHIDS.}

\author{
By P. H. Timberlake,
}

Bureau of Entomology, Washington, D. C.

A few weeks ago some cocoons of Praon were discovered on a rose-bush brought to the Gypsy Moth Parasite Laboratory from a local greenhouse, and at the suggestion of Mr. W. F. Fiske, the opportunity was seized of making a brief study of the early stages of this common parasite of aphids.

Accordingly a small number of the cocoons was secured, and as the imagines emerged they were enclosed in a small glass cylinder with a sprig of rose and a few aphids. The females were not observed to mate with the males, but were frequently seen ovipositing in the plant-lice. The oviposition habits are like those of other Aphidiines as already described many times. The female bends the tip of her abdomen between her legs, and by a sudden trust darts it under her head into the abdomen of the helpless victim, completing the act in a moment of time.

By the dissection of parasitized aphids from these simple reproduction experiments, the eggs, first and second stage larvæ were easily secured, and the third stage larva was as readily obtained by opening fresh cocoons.

The eggs are undoubtedly placed one at a time in the abdomen of the host, and lie free among the organs and tissues beneath the integument. They are minute, ovoid bodies, white in color, of no special characteristic form or appearance. Like the eggs of Platygaster as observed by Marchal $^{1}$ they double and triple in size before hatching. This increase in size is able to take place, probably on account of the plastic nature of the chorion, which expands as the

\footnotetext{
1 Paul Marchal. Recherches sur le biologie et le développement des Hyménoptères parasites. Les Platygasters. Arch. Zoöl. (Paris), Vol. 4, pp. 485-640.
} 
embryo grows by the absorption of food and fluids from the surrounding body fluids of the host.

The first stage larva proved to be of unusual interest, and of specialized structure as is so frequently the case in first stage larvæ of hymenopterous parasites. A short description of it with an outline drawing will follow later in this paper. Its extraordinary taillike appendages are probably respiratory in function, and the comb-like arrangement of bristles on the dorsum seems to indicate that it may thereby be able to move about among the organs and tissues of the host. The assumption that the bristles may aid in its locomotion is strengthened by the fact that they all point backward, are undoubtedly of sufficient size and firmness, and occur most abundantly on the posterior part of the body where they would be most useful.

After the first molt the larva loses its extraordinary appearance and assumes the form of the ordinary hymenopterous larva. During the second stage it increases rapidly in size and begins to make inroads upon the tissues of the host, though as yet carefully avoiding the vital organs. Finally in the third and last stage the larva quite destroys all the organs of the host, including the numerous embryo aphids which the mother aphid carries in her abdomen, and after sucking up the last juices, it leaves its host as a perfectly dry shell, in order to spin underneath a characteristic white cocoon, which has been figured and described by previous authors. ${ }^{1}$

Specimens of the Praon under observation were sent to the Bureau of Entomology at Washington and identified by Mr. H. L. Viereck as Praon simulans Prov. The aphid acting as host was likewise determined by Mr. Theo. Pergande to be the common rose-aphid Macrosiphum rosa L. Another aphid common in the local greenhouse on carnations also proved to be host of this species though less frequently attacked.

From cocoons of Praon were obtained several species of secondaries. One a species of Encyrtid was obtained under such conditions as to make it extremely probable that this species does not attack the cocoons of Praon directly, but lays its eggs in the body of the aphid, where after hatching the larva would seek out the Praon

1 For figure of cocoon see Howard, Insect Life, Vol. 4, p. 196. 
larva, enter it and finally destroy it. Only one Encyrtid was reared from a cocoon.

From a number of cocoons collected from rose-bushes recently placed out of doors at the greenhouse, there was reared a species of Xystus of the family Figitidæ, and also a species of Pteromalid of the genus Asaphes.

While making observations on Praon at the greenhouse we found another species of the Aphidiinæ rather abundant and confining its attack principally to the above-mentioned species of aphid on carnation, though occurring less commonly on the rose-aphid. This species is possibly the European Aphidius rose $\mathrm{Hal}$.

Encouraged by the interesting results with Praon we started reproduction experiments with this species and soon secured the early stages. The first stage larva proved to be far less specialized than that of Praon as it lacks the dorsal combs of bristles, and the tail-like appendanges. A description with drawing is appended with that of Praon.

Specimens of the aphid host were also collected at the greenhouse and dissected. The results are exceedingly instructive and may be tabulated as follows:

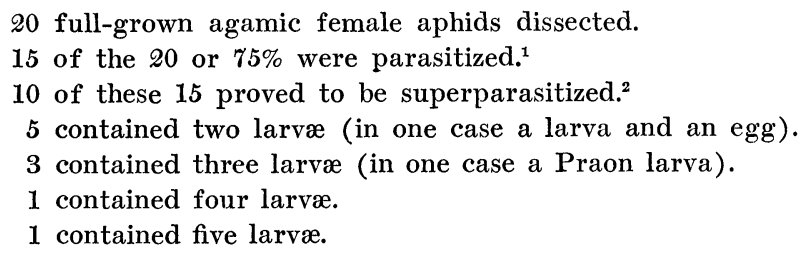

20 full-grown agamic female aphids dissected.

15 of the 20 or $75 \%$ were parasitized. ${ }^{1}$

10 of these 15 proved to be superparasitized. ${ }^{2}$

5 contained two larvæ (in one case a larva and an egg).

3 contained three larvæ (in one case a Praon larva).

1 contained four larvæ.

1 contained five larvæ.

Adding up the number of larvæ or eggs found in these 15 aphids we have a total of 33 , only 15 of which could have ever reached maturity, leaving 18 to perish, more than three times as many needed to destroy the five unparasitized aphids, if the eggs had been distributed more equitably.

These results are the more remarkable when we consider that oviposition took place under normal conditions in a well-lighted

\footnotetext{
1 Two of the fifteen parasitized aphids contained larvæ so far advanced that they had already destroyed every trace of any supernumerary larvæ that might have been present previously.

2 See W. F. Fiske's paper, Superparasitism : an important factor in the natural control of insects. Jour. of Econ. Ent., vol. 3, no. 1, pp. 88-97.
} 
and high-posted greenhouse, where host and parasite were free to follow the natural course of their instincts. They indicate how difficult or rather impossible it is for a parasite ever quite to exterminate its host, as some individuals, perhaps in more exposed positions, will be parasitized again and again, whereas others, probably less exposed, may escape destruction altogether.

An interesting problem that deserves more attention than we have had time to bestow upon it is the fate of the supernumerary larvæ. The few observations already made upon this point are, however, instructive. In most cases the supernumerary larvæ were apparently already dead, being sometimes somewhat disintegrated though bearing no marks of violence. As in all the cases where dead supernumerary larvæ were found there was still an abundance of tissues and liquids in the host for food, we cannot suppose that they were starved, nor, as there were no marks of violence found on them, can we suppose that they were killed in an active combat with a larger and older larva. We may be unwilling to believe that the more advanced and stronger larvæ secrete or excrete some fluid or material into the body of the host which eventually destroys their younger or weaker brothers and sisters, but this view seems forced upon us. This gains the more credence when we stop to consider that by some subtle influence the weak and often insignificant parasite frequently causes important pathological changes in the body tissues of its more powerful host. We have noticed this phenomenon not only in case of parasitized aphids, but also in caterpillars, notably in brown-tail caterpillars parasitized by Meteorus. The change we have in mind is the breaking up of the flaky fat-bodies into small, more or less globular bodies which are unattached and float freely in the body fluids. When in this condition the fatty tissues may be more accessible to the parasite as food.

In no case were the dead larvæ found surrounded and being destroyed by the phagocytes of the host, as we have lately observed in studies on the larvæ of Limnerium, the results of which we hope to publish shortly.

Description of the Larval Stages of Praon and Lipolexis.

I. Praon simulans Prov.

First Stage Larva: Body 14-segmented, somewhat tapering behind; last segment with a dorsal-median, cylindrical appendage nearly as long as the 
preceding segment, tipped with a few short hairs, and a pair of ventral appendages much more delicate, only about half as long as the dorsal appendage. The metathoracic and first to ninth abdominal segments provided with a comb of comparatively coarse bristles along their posterior

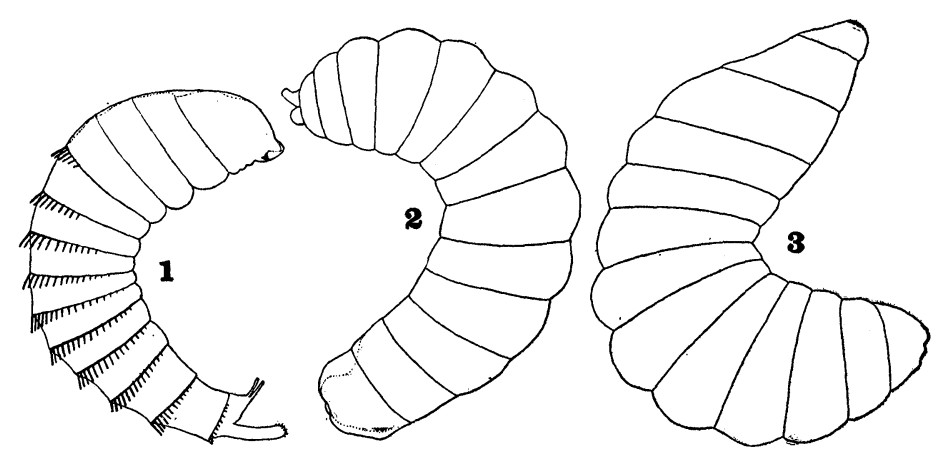

Fig. 1. Praon simulans Prov. 1, First Stage Larva; 2, Second Stage Larva; 3, Third Stage Larva.

margins; the comb extending nearly to lateral-ventral margins on the posterior, but becoming more and more dorsal on the anterior segments. Mouth-parts not prominent, though a pair of small but sharp and chitinized mandibles may be made out. Length $.8 \mathrm{~mm}$.

Second Stage Larva: Like the ordinary hymenopterous larva. Body 13-segmented (owing to the fusion of the last two abdominal segments), tapering but little at both ends. Last segment broadly rounded, somewhat indented at the tip. Head small, mouth-parts appearing as fleshy folds. Integument of body delicate and smooth.

Third Stage Larva: Resembles the preceding stage, but tapers more at the anterior end. Head small, the mouth-parts represented by folds with chitinous plates, not at all prominent. Integument rather thick and chitinous, thrown into large folds along lateral margins of body, everywhere roughened by fine granulations. Length nearly $2 \mathrm{~mm}$.

\section{Aphidius rosae Hal. (?).}

First Stage Larva: Body 14-segmented, rather broad anteriorly and somewhat depressed, tapering gradually behind, the last segments rather deeply constricted, especially anteriorly. The head provided with a pair of projecting lobes on its posterior ventral margin on either side. Mouth-parts represented by a pair of comparatively long, curved mandibles, tipped with a yellowish spot, and prominent when protruded. Body smooth, free from hairs or bristles. Length $.8 \mathrm{~mm}$. 
Second Stage Larva: Not readily distinguishable from the second stage larva of Praon.

Third Stage Larva: Very similar to same stage of Praon, except that it is slightly larger and head is more pointed. Length nearly $2 \mathrm{~mm}$.

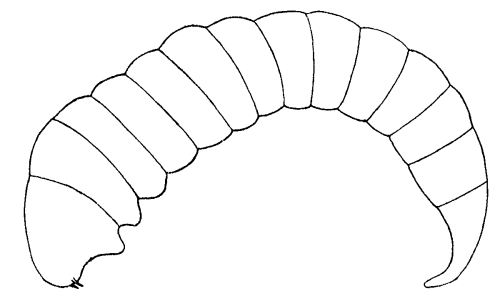

Fig. 2. Aphidius rosa Hal. (?). First Stage Larva.

Before concluding we wish to take this opportunity of expressing our gratitude to Messrs. Viereck, Pergande and H. S. Smith for the determination of specimens.

\section{TRICRANIA SANGUINIPENNIS SAY.}

A female specimen of this species was taken on the under side of a piece of board in a sand pit in Framingham, Mass., April 16, 1905 , and with it was a large mass of what I have considered to be the eggs. They are now very much shrunken and discolored but seem to be elongate oval in shape, measuring more than half a millimeter in length and about one third as wide.

The other inhabitants of this sand pit are Cicindela rugifrons, C. generosa, and possibly a few sand burrowing hymenoptera.

A male specimen of this beetle has recently been brought to me; this was also found in a sandy place. These two specimens are the only ones that I have seen from this locality.

C. A. Frost. 

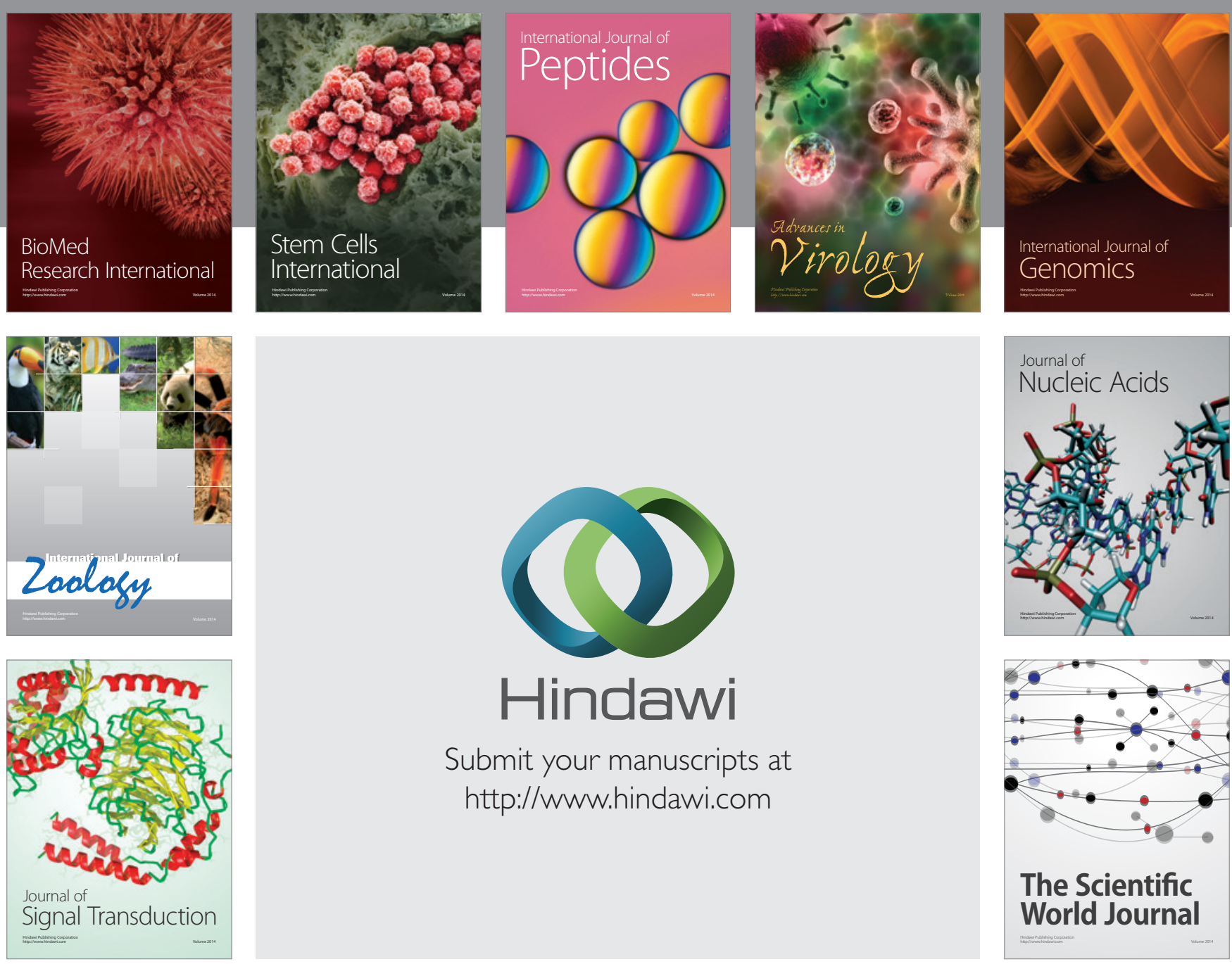

Submit your manuscripts at

http://www.hindawi.com
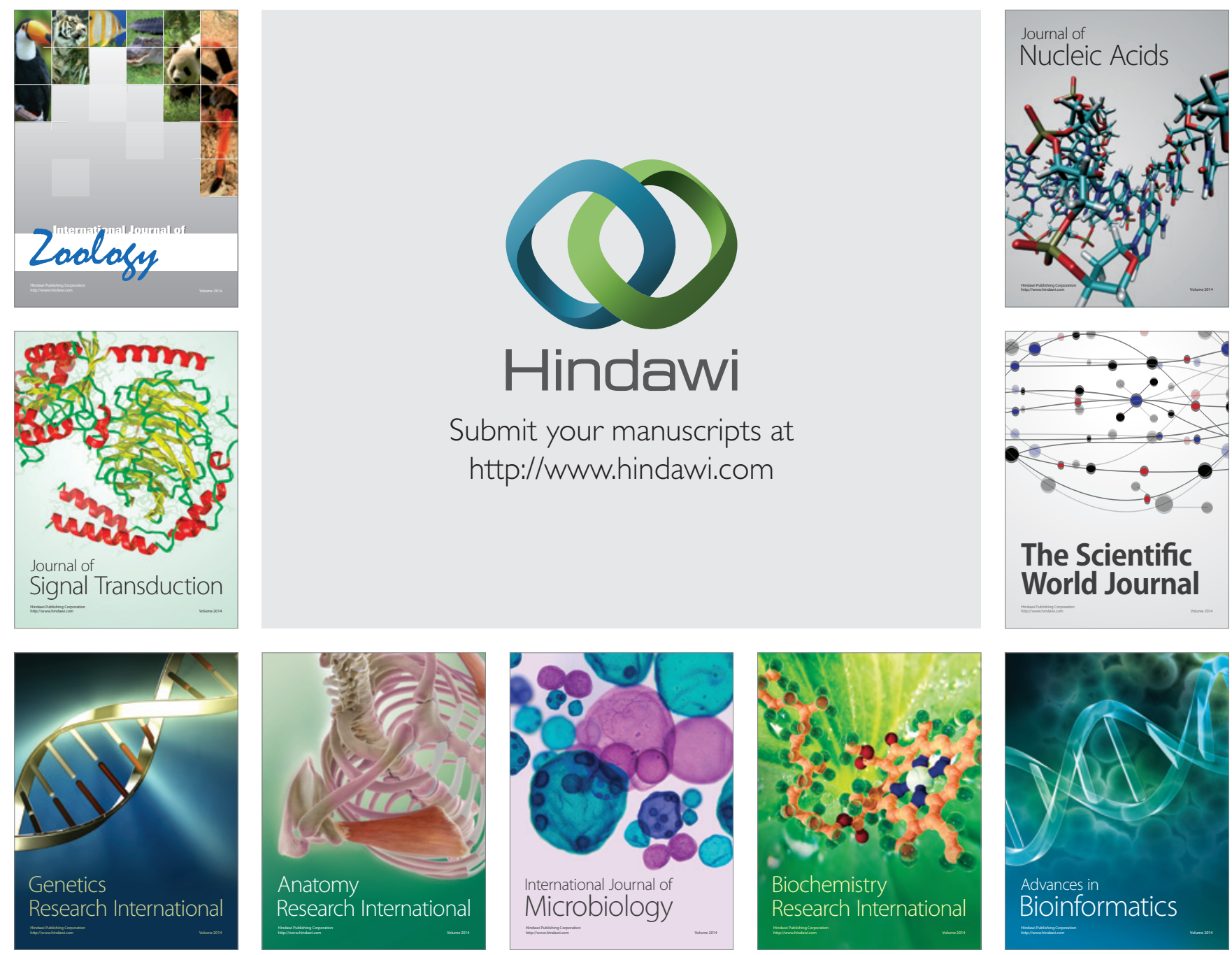

The Scientific World Journal
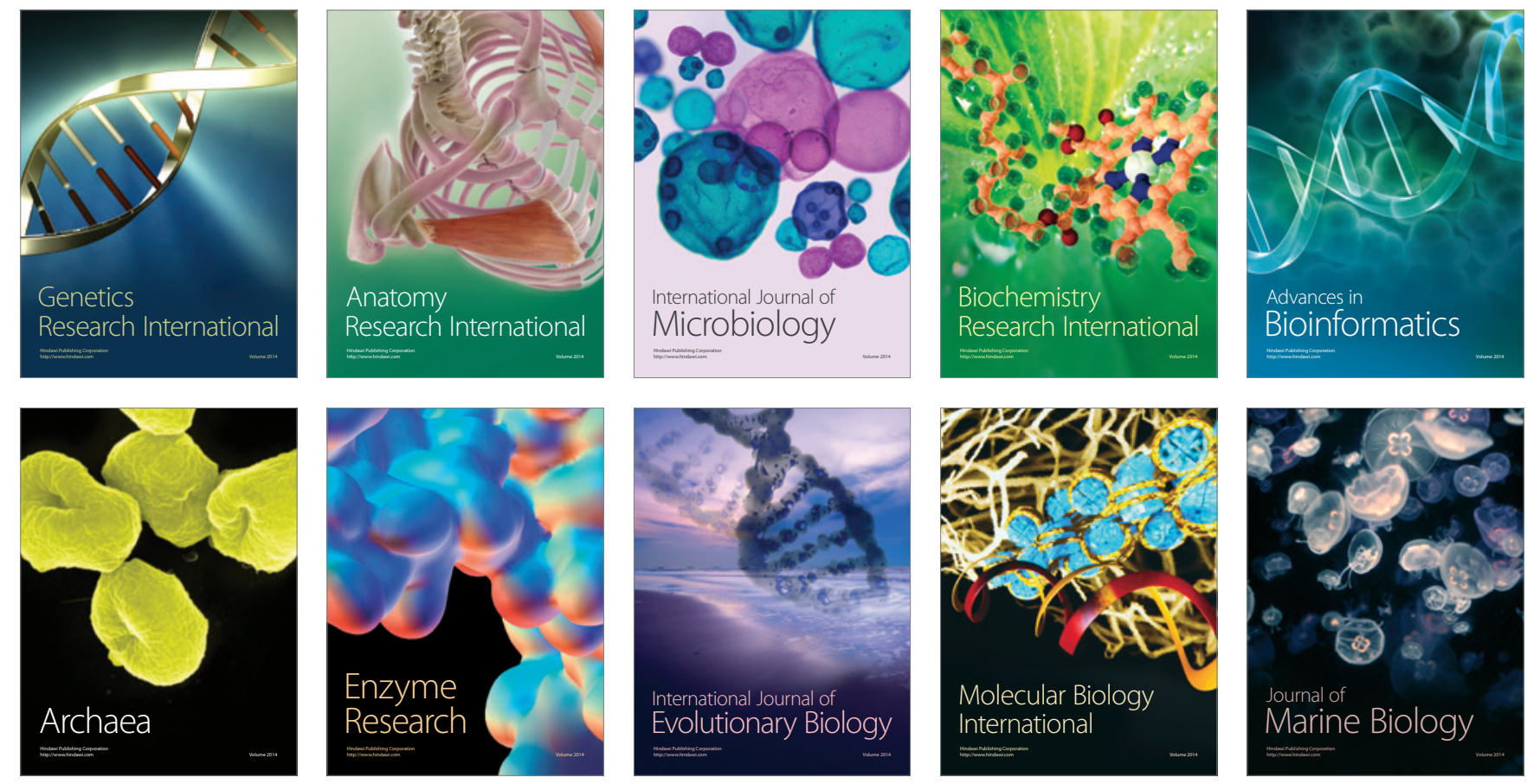